ARTICLE

Received 28 Feb 2017 | Accepted 11 Apr 2017 | Published 23 May $2017 \quad$ DOl: 10.1057/palcomms.2017.36

\title{
Day in, day out: pop goes the city
}

\author{
Stephen Redhead ${ }^{1}$
}

ABSTRACT Today we are inhabiting an era of accelerated digitized global capitalism, what Slavoj Zizek calls the "new dark ages" and Alain Badiou refers to as the "dialectics of black". The need is for updated new theorization of this formation and better empirical accounts. This essay looks at the recent development of digital leisure cultures around popular music in Manchester (UK) especially since the global financial crisis, which still permeates our globe in unforseen ways. This understanding of the contours of a rapidly accelerated digitized capitalism utilizes various resources. Building on this idea this article argues that what we see as "claustropolitanism" (the feeling that we want to escape the planet because we are now so foreclosed) is fast becoming a post-crash cultural condition spreading globally. For Paul Virilio, who is claustrophobic, Joy Division's mantra "feel it closing in" from "Digital" is personal, but the mediatised global pop culture is also experiencing the same feeling. This paper draws on the author's long-term empirical research into the city of Manchester and its popular cultural history to tease out some theoretical implications for the study of digital society and capitalism in general.

\footnotetext{
${ }^{1}$ Flinders University, School of Humanities and Creative Arts, Adelaide, South Australia, Australia Correspondence: (e-mail: Steve.Redhead@flinders.edu.au)
} 
I Feel It Closing In

Day In, Day Out

Day In, Day Out

\section{Joy Division, "Digital” (Factory Records)}

$\mathrm{n}$ the analogue age Manchester popular music development was linear. In Michael Winterbottom's early 2000s fictional film Twenty Four Hour Party People the period of music history of the city which was covered was 1976-1996 (Wilson, 2002). This, coincidentally, was the exact period covered by Robb (2009) lead singer of The Membranes and Gold Blade in his compelling oral history of the Manchester's popular music. Since then we have had inexorably rising digitization, with its mantra of digitise-upload-share shifting the goalposts at every turn. The period since the mid-1990s has given rise to a digital age of music history which doubled back on itself in cyclical fashion. As Jon Wozencroft says in Grant Gee's Joy Division documentary from 2007 Joy Division's "Digital” from the late 1970s is Digital-Day In, Day Out as the lyrics say (like Zeros and Ones). Day in, Day Out, relentless, unstable, precarious. Digital capitalism is, like an amoeba, all consuming, producing claustropolitanism, entertaining us all to death.

Now we are in an era of accelerated digitized global capitalism - what Zizek (2014) calls the "new dark ages" and "trouble in paradise" and Badiou (2017) refers to as the "dialectics of black"-we urgently need new theorization of this formation. This essay looks at the recent development of digital leisure cultures around popular music in Manchester especially since the global financial crisis which still permeates our globe in unforseen ways especially in the rise of a radical right wing populism in the United Kingdom, Australia and the United States. This understanding of the contours of a rapidly accelerated digitized capitalism utilizes theorists such as Alain Badiou, Slavoj Zizek, Jacques Ranciere and Paul Virilio who pertinently illustrate the risks of these developments for our calls for social justice and for future sustainability of the globe. These theorists are deployed in this essay with a view to producing better theorising of the "digital turn" in global capitalism.

French urban theorist of speed Paul Virilio in conversation with Sylere Lotringer (Virilio and Lotringer, 2008) has claimed that we are moving from cosmopolis to claustropolis. Building on this idea I argue that "claustropolitanism" (the feeling that we want to escape the planet because we are now so foreclosed) is fast becoming a post-crash cultural condition spreading globally partly created by the compression, non-linearity and technological alienation, or false intimacy, of digitization. For Paul Virilio, who is claustrophobic, Joy Division's mantra "feel it closing in" from "Digital" is personal, but the mediatised global sporting and pop culture is also experiencing the same feeling. The research I have conducted in Manchester includes personal interviews and correspondence, deep ethnography and archival work. I draw throughout this essay on this rich long term empirical research into the city of Manchester and its popular cultural history and popular music heritage, which even helped to produce an historical archive called Manchester District Music Archive or MDMA for short (Champion, 1990; Lee, 2002, 2007; Baker, 2015) preserving the popular music history in both analogue and digital forms. In this essay I try to tease out the theoretical implications for the study of digital society and capitalism in general. It is a mashed up mixture of high theory and raw realism.

\section{Northern bauhaus}

Peter Saville, design guru at Factory Records (Robertson, 2006; Middles, 2009; Nice, 2010), christened the city of Manchester "original modern", on becoming the Creative Director for Manchester City Council in 2004. When I was first researching popular culture in the "original modern" industrial city in the mid-1970s there was actually such a thing as "Manchester studies" in higher education. Now in the present day Manchester University Press, publishers based in the city at the University of Manchester, have a book series entitled Manchester Studies in Modern History. The students who were on this track at Manchester Polytechnic in the mid-1970s were part of historical studies courses and popular music hardly featured at all in those days. Today the history of the city's popular music would be a central part of what I call "Post-Manchester Studies", however it is conceived. At present Manchester is "buzzin", as the locals would say. With the arrival in summer 2016 of the two best coaches in modern world football at Manchester City and Manchester United respectively a new global media circus narrative is being written. Manchester as Music Football CityPep and Jose! Roll Up, Roll Up! Pep Guardiola and Jose Mourinho have met before as rivals in Spain with eye gouging and high drama on the daily agenda but this situation is something new for both. Manchester, as the post-industrial city is ripe for this rivalry. Football and popular music have crossed over in Manchester for decades. Pop goes the City! The first interview done by Pep Guardiola when he arrived in Manchester was not with a sports journalist but with Oasis and High Flying Birds' singer, songwriter and guitarist Noel Gallagher, an avid and knowledgeable lifelong Manchester City fan (Middles, 1996; Moody, 1996; Gallagher and Christian, 1996; Hutton and Kurt, 1997; Hewitt, 1997, 1999; McCarroll, 2010).

The popular culture of Manchester as a whole is taking off but not necessarily in the way that right wing politicians like David Cameron and George Osborne perceived it. The UK Conservative government buzzword for Northern cities like Manchester in the London-centric state has for a few years now been Northern Powerhouse-a phrase cynically regarded by those who live in the North West especially when it comes from the mouth of a Tory Chancellor like Osborne whose own job was forefeited after the Brexit referendum to leave the European Union, part of the general rise of the right globally. Former Prime Minister David Cameron once loudly proclaimed his Smiths fandom and Johnny Marr, guitarist with The Smiths, immediately rejected it with the unmitigated contempt of a musician who had formed The Smiths in an anti-Thatcher era (Middles, 1985; Carman, 2006; Marr, 2016). Since the Brexit debacle new Prime Minister Theresa May has signalled the end of the phrase, and the policy, complicating the rhetorical call to move from Cottonopolis (as Manchester was once dubbed historically) to Northern Powerhouse.

Because Prime Minister May ditched Northern Powerhouse very quickly, Manchester needs to reimagine the city and its culture in the new dark ages we are being plunged into globally. A different history of digitized art, music, media, sport and politics beckons and gives a better explanation and hope for cities in the United Kingdom and elsewhere for a post-global financial crisis future. My more appropriate label Northern Bauhaus has a good ring about it and is only partly tongue in cheek for it can be sustained in an argument about the city's popular music history as well as its football history. Post-war Manchester boasts a rich pop cultural tapestry (football, film, poetry, art, popular music, TV drama) which is unlikely ever to be repeated in intensity in one city anywhere else in the world.

\section{Digital manchester}

Digital Manchester though goes on apace. For example, the postindustrial Sharp Project (named after Sharp the electronics company on whose abandoned premises the project stands), a 
creative industries project par excellence including work space in shipping containers, sound stages and cutting edge technology, also began and started to grow. We are, in an era of global digitization, as Jacques Ranciere has reminded us today (Ranciere, 2009: 17-22) looking back on the end of the image: "the end of the images is behind us" (Ranciere, 2009: 17).

Digitization with its never ending mantra digitise-upload-share has created a "mourning" for a previous system of producing images (Ranciere, 2009: 18) which resonates with the "mourning" of the music of bands like Joy Division and early New Order (Edge, 1988; Flowers, 1995; Thompson, 2005; Middles and Reade, 2006; Hickey, 2012; Bickerdike, 2016; Butterworth, 2016). Since Ian Curtis, Stephen Morris, Bernard Sumner and Peter Hook began playing regularly as Joy Division in 1978, that's effectively 29 years up to 2007 (Morley, 2007) when the Curtis-less New Order officially ended their reign in the rainy city. The year boss of Facory Records and Hacienda Tony Wilson died. Twenty nine years since the beginning with Peter Hook and Bernard Sumner its longest serving artists; if you take the first Sex Pistols gig, which Hook and Sumner attended along with Pete Shelley, Howard Devoto and all the other "Manchesterati", at the Lesser Free Trade Hall in Manchester in June 1976 (Nolan, 2007a) as the point of origin it is actually thirty one years. The reformed (without Peter Hook, replaced by Bad Lieutenant's Tom Chapman) New Order in 2011 hardly alters this history-Hook's caricature of the band as "New Odour" speaks volumes for the legal and personal wrangles which have developed since the "final" split in 2007 (Beaumont, 2012; Harrison, 2012). A new New Order and Peter Hook's The Light roared back with their own projects which are still lighting up the whole world with global tours and new releases. Hook's the Light especially specialised in entire live sets of earlier Joy Division and New Order music many of which have now been digitized. Long time icons of Manchester popular music The Fall (Middles and Smith, 2003; Wild, 2007; Simpson, 2008; Smith, 2008; Goddard and Halligan, 2010; Start Smith, 2016) and The Stone Roses (Cawthorne, 2005; Green, 2006; O'Connell, 2006; Middles, 2012; Spence, 2012) are also still playing to packed houses, the latter to much global acclaim after a reformation decades after they had first broken up. For Manchester bands like these from the analogue age the back catalogues have been digitized erasing all the historical highs and lows for new audiences and fans (Duffet, 2014) in the digital age.

Zizek (2013) has reflected, in answering chapter length questions from Yong-june Park, on the rapidly changing internet and its promotion of so-called "postmodern economy" leisure pursuits. Zizek muses on the acceleration of digital leisure cultures and the attendant homogenization, miniaturization and digitization:

Let's see what is now happening on the internet. We get, more and more, to serialise our lives: we go to see the same movies and we watch the same news. People describe it as a movement towards the clouds: cloud computing. We no longer need a big computer to play video games, like the one I have in my room to have fun with my son. (Zizek, 2013: 6)

\section{In Zizek's view:}

A decade ago, a computer was a big box on one's table, and downloading was done with floppy disks and USB sticks; today, we no longer need strong individual computers since cloud computing is internet based-ie. software and information are provided to computers or smartphones on demand, in the guise of web-based tools or applications that users can access and use through a browser as if were a programme installed on their own computer. (Zizek, 2013: 6)

\section{Zizek concludes from this that:}

In this way, we can access information from wherever we are in the world, on any computer, with smartphones putting this access literally into our pocket. (Zizek, 2013: 6)

For Zizek, though he is a fan of the digital world, there is a perceived danger in the virtual-homogenization, monopoly and standardization in the internet and the web. He agonizes that:

Everything happens out there. Are people aware how this will standardize everything? We will only be connected to one single provider, like Google or iTunes, but we are limited to their choices. Our struggle should thus focus on those aspects that pose a threat to the transnational public sphere. Part of this general push toward the privatization of the "general intellect" is the recent trend in the organization of cyberspace towards "cloud computing". (Zizek, 2013: 6-7)

In general despite his misgivings Slavoj Zizek is in favour of the accelerated culture that is being generated by these technological changes which some see as the heralding of a new leisure society and others the onset of a precarious work future (Standing, 2016; Urry, 2016). The effects of digitization, globalization and neoliberalism are wide ranging. Despite the rise of the right globally, and the concomitant economic and political nationalism and deglobalization, the structure of feeling of the modern world is what I call claustropolitan (Redhead, 2011). Ultra-realist criminologists Steve Hall and Simon Winlow have utilized my concept of claustropolitanism capturing its essence and linked it to the thinking of Alain Badiou:

Redhead's notion of claustropolitanism-based on Virilio's claim that humanity increasingly wishes to get off the planet and leave behind the depleting, overcrowded, gridlocked and corrupt world of neo-liberal mega-cities, resource wars, clamorous markets and petty consumerised struggles for social status-contextualises Atkinson's notion of the "metropolitan cloud" as the first actual step, both metaphorically, and in some ways literally, in this process. In the vortices, the retreat of younger generations into subjectivity and fantasy is the pallid substitute for what the rich are beginning to do in reality...Alain Badiou said something similar-at the moment judging by the way we think and what we desire, as disembodied subjects running away from reality we all, as Redhead implies, want to be "out of this world". (Hall and Winlow, 2015: 128-129).

Claustropolitanism in the original modern city is the way in which digitized popular music history of Manchester is experienced.

\section{Pop city}

There was, of course, much pop musical city life in Manchester before Joy Division and New Order-Lawson (1992), for instance, wrote a now long out of print book in the early 1990s called $I t$ Happened in Manchester (the cover design involving crossing out Liverpool and substituting Manchester instead) which culturally mapped the huge beat explosion of the city in the late 1950s and early 1960s (essentially the years from 1958 to1965), a 
phenomenon which eventually produced the later international pop world of The Hollies, Freddie and the Dreamers, Herman's Hermits, Wayne Fontana and the Mindbenders and The Dakotas. Post-war Manchester boasts a swathe of rich pop cultural history, now being digitized in avariety of ways. Tony Wilson always used to answer reporter's questions about "why Manchester?" with the rather glib point that "Manchester kids" record collections were better' although he was actually quoting someone else when he said those words.

Some more substantial factors behind the city's popular music overdrive have also been offered by commentators. A strong factor is the rich history of clubs and venues-the Twisted Wheel and The Hacienda were only the best known (Savage, 1992; Haslam, 1999, 2015; Rylatt and Scott, 2001; Nolan, 2009; Sykes, 2012; Hook, 2009) of many hundreds of clubs and venues. Manchester also had a singuar producer, Martin Hannett (Sharp, 2007; Hewitt, 2014) who through astonishing and far sighted explorations in digital recording technology marked out a different territory to everyone else at the time especially on Joy Division's debut album Unknown Pleasures (Kennedy, 2006). This is the reason the music sounds as contemporary today as it always did. Another one of those reasons is the choice of recreational drugs and the large illegal markets it produces and popular musical connections it forms (Spence, 2012, 2014; Spence et al., 2013). Since the 1950s marijuana and amphetamine, some of the cognoscenti argue, gave Manchester its specific mobile city culture even though in the mediatised public mind it is Ecstasy (MDMA) which stands out as the drug with which the city is associated for the brief "Madchester" ("Rave On" as the Happy Mondays' Wilson inspired EP had it) period in the late 1980s.

I wasn't at the Lesser Free Trade Hall at either of the two now historic Sex Pistol appearances in summer 1976 (Nolan, 2007a) but I do vividly remember, as an ethnographer, walking nervously through Collyhurst to see punk bands including The Slits and Buzzcocks at the Electric Circus in May 1977 just as massive flares gave way to straight legs and long hair mutated into spikey. Many histories start on the cusp of this change in Manchester music and wider youth culture-Tony Wilson himself, an undoubted influence on all that followed, was still going to see local pop/ rock bands like Sad Café (with Paul Young, later of Mike and the Mechanics, on vocals) in this period even in the wake of the Sex Pistols and all that "gobbing on life" as Alberto Los Trios Paranoias put it in song (Lee, 2002, 2007). Salford punk poet John Cooper Clarke was reading "Beasley Street" out loud in Cheshire folk clubs just to get heard whilst still-gigging Solstice, a local (non-punk) rock band, played alongside the Sex Pistols at the Lesser Free Trade Hall in 1976.

\section{Off world sounds}

Digitally Manchester has moved "off world". I want to draw on my research logs here to illustrate its global pull and push. A DAT (Digital Audio Cassette) belonging to Manchester exile Pete Carroll (Shaun Ryder's cousin) passing between Manchester and Perth in the late 1990s/early 2000s expanding the roster of Western Australian labels Offworld Sounds (OWS) and littleBIGMAN is one example. One of Salford's unsung sons, and most creative entrepreneurs, Pete Carroll is living and working in exile in Perth, Western Australia. Pete is Shaun Ryder's cousin and also a lifelong Manchester United fan. His brothers, Pat and Matt Carroll, made up the design company Central Station Design whose demented colour portraits epitomized the Ecstasy culture of Madchester in the late 1980s and early 1990s. Central Station Design produced covers for Factory (Robertson, 2006), including Happy Mondays, as well as Black Grape, the grotesque Carlos the Jackal design being the most infamous.
In Richard Macer's difficult-to-watch 2003 TV documentary "The Ecstasy and the Agony", made about the trials and tribulations of Shaun Ryder, Pete's suburban house in Western Australia featured strongly and Carroll himself talks intimately about Shaun Ryder to camera a fair bit in the film. Original Central Station Design Pop Art work adorns the walls of Pete Carroll's house. A personal favourite is the portrait of comedian Arthur Askey, but they're all stunning. Carroll emigrated to Australia in the early 1990s. A few years down the road he met up with fellow émigré Stephen Mallinder (from Cabaret Voltaire) who had recently forsaken the United Kingdom for Western Australia. In 1996 they started a dance record label together called OWS (Offworld Sounds). Perth is nearer to Singapore than Sydney and is the most isolated capital city in the world hence the "off world" tag. OWS has been the vehicle for various projects including Shane Norton's Soundlab, Mallinder's Ku-Ling Brothers and Sassi and Loco, and many other rare treats from modern electronica. In late 2000 at the end of a Happy Mondays tour which finished in Perth, Gaz Whelan from the Happy Mondays and Pete Carroll decided to start another, more rock oriented label. The result was littleBIGMAN Records. In 2003, Off world Sounds released Amateur Night In The Big Top, with Stephen Mallinder and Shane Norton playing and taking production credits and Pete Carroll organizing everything. In $2004 \mathrm{Bez}-$ originally named Mark Berry (Berry and Faulkner, 1998)_from the Happy Mondays and Black Grape (Middles, 1997; Verrico, 1998) and Celebrity Big Brother winner and sometime political candidate for Salford, with Shaun Ryder on backing vocals, released his one and only single to date on littleBIGMAN Records called "Rattle My Head" (b/w a mix called "Right in My Head" and an extra track "Heebie Jeebies"). Bez singing!? Pete Caroll and Gaz' Whelan's littleBIGMAN label had an interesting roster, including The Panics (managed by Carroll) for many years Perth's best kept rock music secret.

Amateur Night in the Big Top was made in strange and affecting circumstances. It was recorded in Pete Caroll's small garage studio at his home in Perth with Shaun Ryder recovering from a near death trauma. The final leg of the Happy Mondays tour of Australia which ended in Perth saw Ryder at the end of his tether. Years of drug abuse, and legal problems with previous management which prevented him earning any money at all officially since the mid-1990s, had finally caught up with him. He nearly died. Carroll's family in Perth came to the rescue and somehow, over several months, Ryder recuperated and recorded some of his best work for an album which would make him exactly nothing. The eight long tracks comprise "The Story", "Long Legs", "Scooter Girl" (which was released as a single), "Clowns", "Murder", "Northern Soul Brother (Shapeshifter), "Monster" and "In 1987". They all feature Ryder's famous garbled loose-fit lyrics, though more slurred than ever, with excellent backing sounds, mostly conventionally electronic but with occasional pedal steel guitar from Lucky Oceans. Central Station Design provided the artwork, as well as the video for the single. The cover and inside artwork has the "mad" portraits syndrome in overdrive-George W. Bush, Hitler, Saddam amongst others all got a slot.

\section{Creative industries and the knowledge economy}

One contemporary way of understanding music cities is through "creative industries" debates. Popular music is seen to be one of more than a dozen industries classified as creative industries and subject to ever changing local, national and international cultural policies. Always interested in intellectual life, however obliquely, Tony Wilson, after a while, cottoned on to these debates and briefly fell head over heels for the ideas of one of the gurus, US 
management theorist Richard Florida (Florida, 2005a, 2005b, 2008,2010, ,), in the mid 2000s. The idea of "the creative class" in Florida's work helped to explain to Wilson what the previous anarchic forty years had been about, in particular his own personal biography as "Mr Manchester" (Reade, 2010). Also it helped him see what the future might hold for his beloved Manchester and surrounding hinterland. For Wilson, young creatives, or creative entrepreneurs, abounded in the North West and he even went as far as to write a Florida-influenced report on the "post-industrial" Pennine region and its creative potential. As Tony Wilson stated enthusiastically in 2005:

Please don't think the idea of name-checking Richard Florida is redundant for poor old East Lancashire....artists are already moving to Bacup, and Ramsbottom is already a desireable suburb for young creatives in Manchester. (Carter, 2005: 15)

Even before this, in the early 2000s, Wilson had been a prominent participant at the inaugural meeting in the city centre of The Independents, a group of Manchester-based small entrepreneurs (from stall holders to music label owners) inspired by the theories of creative industries and the knowledge economy by British researchers like Charles Leadbeater and Kate Oakley (Leadbeater, 1998,1999, 2002,2009,; Leadbeater and Oakley, 1999,2001). Wilson, as he often did, mixed this intellectual context with the rough, populist popular music world he inhabited when he wasn't doing his middle class day job at Granada TV. For Wilson this concentration on the "knowledge economy" was the digital future for Manchester and its popular music culture. In 1992, ironically just before the bankruptcy of Factory in the November of that year, Tony Wilson joined the board of the Manchester Institute for Popular Culture (MIPC) which I had set up with my colleague Derek Wynne at Manchester Metropolitan University. In the next three years he gave his time freely to us despite the enormous impact of Factory's financial troubles and was always keen to plug into the MIPC debates/studies/seminars about what I call "mobile city cultures" (Redhead, 2011), especially where popular music and Manchester were concerned.

The notion of mobile city cultures explains the longevity of Manchester as "Pop City". Whereas most music cultures in second tier cities (Liverpool, Seattle, Dusseldorf, Dunedin) have, as Wilson himself noted, their "three years in the sun", Manchester maintained its pole position for at least the period 1976-1996. The fact that Quando Quango's bass lines were picked up by black Chicago house musicians in the mid-1980s and then recycled back to Manchester on the dancefloor of the Hacienda is one example of mobile city cultures.

Another explanation for Manchester music's sustainability is, though, the anti-Factory subculture that existed for decades. Factory wasn't a major label; it was an independent. But in the context of Manchester and the North West, Factory was as good as a major. Its very existence, as well as its dominance in the media, caused resentment locally and the small labels which popped up from time to time over the years (Dave Haslam and Nathan McGough's Play Hard, Paula Greenwood's Playtime and so on) were formed in a counterculture "against" the Factory line. "Outside" influences were important, too, implicitly questioning the one dimensional Situationism of Factory and expanding the range and reach of what Manchester music meant-DJ Steve Barker's "On The Wire" BBC Radio Lancashire programme broadcast from nearby Blackburn, On-U Sound producer Adrian Sherwood's live mixing at gigs in the city, to name just two.
Tony Wilson's famous theory of "thirteen year" cycles in popular music also had its genesis in Manchester music history. The theory went that The Beatles (who often played in Manchester beat clubs) in 1963 represented one musical upheaval, punk in 1976 represented another and acid house in 1989 yet another. The second Summer of Love in 1988 slightly altered this historical sweep but you knew what Wilson meant when he expounded the theory. I remember asking Tony Wilson in 2002 "well, it's time, where is the next big thing?" and being met by an exasperated splutter! It certainly did not occur in Wilson's lifetime and is unlikely to happen anyway, anyhow, anywhere. The analogue age had linearity but, since the digital age beginning in the mid-1990s, the speeded up accelerated culture created only cyclical, circular history. For a while The Ting Tings, from Salford, and Bernard Sumner's Bad Lieutenant post-New Order project were interesting but hardly the revolution in popular music culture predicted by Wilson's enchanting but outdated linear theory of cultural change. However, pop hope springs eternal. The Tens (2010 onwards) began with a solid suggestion that bands like Delphic, whose first record Acolyte was released to critical acclaim, were in the vanguard of a new New Wave:

With their modernist fonts and single-word song-titles, Delphic are sons and heirs of New Order, while their ravey bleeps and beats recall the city's role in the acid-house movement...Acolyte sees them reviving Manchester's preMadchester reputation as the home of arty, Eurocentric, electronic dance pop. (Lester, 2010: 15)

Then in 2012 young Manchester filmmakers Serious Feather produced a ninety minute documentary film, entitled Manchester: Beyond Oasis, documenting, in a diverse coverage of forty bands and singers from Manchester currently playing, the vibrancy of a new era of the Pop City which continues today.

\section{Salford lads club}

The later full blown recovery which eventually got Shaun Ryder clean and the Mondays back on the road with a new album Unkle Dysfunktional to promote in 2007 is fundamentally down to the period up to 2004 when Pete Carroll's efforts, half a world away, to put out ground breaking music from Shaun Ryder, at almost any cost, effectively saved his cousin's life. Pete Carroll, at a distance, worked over recent years with fellow Salfordian Tony Wilson to twin the "In The City" music convention, which Wilson set up with partner Yvette Livesey in the 1990s in Manchester as a response to the New York Music Seminar, with Perth in Western Australia. Wilson's own tragic illness (he was diagnosed with kidney cancer in 2005) prevented the Perth version of In The City going ahead in 2006. One of Wilson's kidneys was removed in 2006. Later, in 2007, as chemotherapy failed, his friends, including Happy Mondays, clubbed together to keep him alive on Sutent, a drug not available in Manchester on the NHS but (ironically) prescribed free in Cheshire. Wilson's death through a heart attack in August 2007 symbolically ended the various partnerships for In The City but Salford Lads Club, metaphorically, will, undoubtedly, live on.

"You Salford Nancy Boy!" was a regular insult hurled from the wings at the late Tony Wilson, educated at De La Salle College in Salford (where iconic pop photographer Kevin Cummins (Cummins, 2002, 2008, 2009, 2010, 2015) was schooled too), before he went to Cambridge University, throughout his time as a Granada TV frontman from the 1970s onwards much as festival crowds chanted "John Peel's a $* * * *$ !" when Peel presented or DJed in the 1970s and 1980s. Both were affectionate jibes, in the 
main, reserved for national institutions. And Wilson was from Salford (born 20 February 1950) though he lived in leafy Marple in Cheshire from five years old. Most of the time that he was involved with Joy Division and New Order through his label Factory Records he lived in the countryside south of Manchester or in South Manchester. As pop writer Jon Savage has pointed out on numerous occasions, unlike The Smiths, none of Joy Division were from Manchester. Bernard Sumner and Peter Hook came from twin-city Salford'. Bernard Sumner (Nolan, 2007b; Sumner, 2014) was born in Salford on 4 January 1956 and Hook (2012, 2016) was born in Salford on 13 February 1956. Punk poet John Cooper Clarke hailed from Salford. Factory also, notoriously, had on its roster Happy Mondays (Warburton, 2000; Spence, 2014) who hailed from Little Hulton, also part of Salford.

The physical Salford Lads Club, at one end of Coronation Street (the real one, though parts of the TV soap in the early 1960s featured the street) in St Ignatius Walk, Salford, was made internationally famous by Stephen Wright's photograph of The Smiths included in the gatefold sleeve for "The Queen is Dead" album in 1986 (Bret, 2004; Godard, 2004; Brown, 2008; Campbell and Coulter, 2010; Fletcher, 2012). Before that era Manchester bands like The Hollies in the 1960s used it for rehearsals. Graham Nash and Alan Clarke of The Hollies had been members of Salford Lads Club as was, a little later, Peter Hook of New Order. In September 2001, with the building in desperate need of repair the Club applied for funding to keep it open. The Grade II listed building needed 1 million pounds worth of repairs in 2007 but much of the money required had been raised since 2005. In 2004 a Smiths room was opened in the club featuring photos and other memorabilia. As Phill Gatenby, author of numerous guides to Manchester's pop locations (Gatenby, 2002; Gatenby and Gill, 2011) notes, Salford Lads Club's famous entrance is:

at the very end of Coronation Street... The original Rovers Return pub was off the end of Coronation Street on Gloucester Street; named The Amalgamated Inn, it was demolished in 1971. Ordsall itself was the original docks estate where A Taste of Honey was set...The Club was originally opened in August 1903 and officially in 1945 by Lord Baden-Powell...it was made a listed building in August 2003 and is considered by English Heritage to be the finest example of a pre-WWI Lads Club surviving in England...The Club still attracts more than 150 young people from Ordsall each week, with football, boxing and snooker being the main attractions. The Club is officially known as The Salford Lads and Girls Club as girls have been admitted since 1994. (Gatenby, 2007: 54)

Salford was always a Manchester United hot bed and New Order (and Tony Wilson much to the chagrin of Manchester City devotee Rob Gretton) vaguely supported Manchester United FC (Peter Hook and Bernard Sumner certainly went to United games as youngsters), the football club based at Old Trafford just across the footbridge from Salford Quays. Ian Curtis (Curtis, 1995; Middles and Reade, 2006; Curtis, 2014) from Macclesfield, lead singer of Joy Division, used to get abuse for being a Manchester United fan even though he actually supported Manchester City. Manchester and Salford have always had a violent image, going back to Victorian gangland (O'Neill, 2008). In the mid-1950s, Salford, according to legend, offered no prospects of any escape. Certainly industrial buildings lay all around, obscuring the horizon, and remnants of the city's history as a once-bustling port and merchant-house city were obvious. Salford, said former resident Ian Hough who wrote two riveting books on the Manchester and Salford casual football gangs (Hough, 2007; Blaney, 2014), was an area which had earned a vicious reputation for bloody violence and murder over many years, the bulk of the activity centring on the docks, always a traditional battleground in which hard men fought.

Fifty years later Salford docks area was manifestly "regenerated" by the Lowry, Daniel Libeskind's Imperial War Museum North and the move of sections of the British Broadcasting Corporation from London to the new Media City in Salford. Based on two hundred acres near The Lowry on Salford Quays there are a huge range of different projects as part of Media City which are intended to generate 15,000 jobs before 2022 . The primary focus is on the creative industries and a general public sector development involving Salford City Council, Central Salford Urban Regeneration Council and North West Development Agency, as well as the BBC, Granada TV and the University of Salford, which will constitute the biggest business and community development project in the North of England. Wilson did not live to see it but he would have been proud to see his beloved region recognized culturally by what he saw, in his fierce civic pride, as the "southerners". The 2011 summer riots across Britain included Salford and Manchester and millions of pounds worth of damage ensued as shops were looted and torched and violent clahes erupted between police and rioters. The gang wars, though, escalated over a 25 years period and Ben Black's book Shooters (Black, 2012) along with Pete Walsh (Walsh, 2003) trace a contemporary history where guns and even grenades created a "claustropolis" rather than "cosmopolis" across both Manchester and Salford (Virilio and Lotringer, 2008). The contemporary digital initiative the Sharp Project, named after the electronics company's former building which houses the hub, is moving in the opposite direction. The "creative industries" and "digital media" hub of Manchester continues to expand, with the city well on the way to becoming "the digital centre of Britain" through innovations like The Sharp Project, home to more than 50 hightech production companies and four sound stages and utilizing shipping containers as creative hub offices.

\section{Original modernity}

As we have seen in this essay, Joy Division's "Digital" from the late 1970s (the analogue age) is actually Digital-Day In, Day Out as the lyrics say (like Zeros and Ones). Day In, Day Out, relentless, unstable, precarious and profoundly dangerous, digital capitalism is, literally, all consuming. My own recent favourite music, digitally downloaded on to IPod Touch and heard through Skull Candy headphones, has to be New Order's Music Complete, released by Daniel Miller's Mute label. The extended dance mixes of the tracks were released all together as an alternative album, Complete Music. Clever, modernist cover art by Peter Saville and his associates, and majestic, monstrous tracks reflecting the last 30 years of dance culture, name checking Gorgio Moroder, the Pet Shop Boys and many others on the way. Even though it seems a profanity to have a New Order album without Peter Hook it is an historic, watershed digital production, with help from Iggy Pop, Brandon Flowers of The Killers and Tom Rowlands of the Chemical Brothers. New Order created a global pop aesthetic in those years; "original modern" I call it after Peter Saville christened the city of Manchester "original modern" on becoming the Creative Director for Manchester City Council in 2004. Saville was Factory's designer and a partner in the enterprise and still art directing for all he is worth on the album cover. They are all revisiting this original modernity in the new version of New Order and Peter Hook's The Light but it was essentially built from early Joy Division beginnings in 1978 and not disrupted for long by Ian Curtis' suicide in 1980 (Curtis, 1995,Bickerdike, 2016). Original modernity is like that. Everyone trying to recapture what was fleetingly new, shiny and vibrant. All that is 
solid melts into air, as Karl Marx and Friedrich Engels once said (Marx and Engels, 1969), in their own, peculiarly long lasting definition of modernity. Music Complete is the digitized popular music sound of living for years in original modernity and the original modern city, resisting the pull of claustropolitanism.

\section{References}

Badiou A (2017) Black: The Brilliance of a Non-Colour. Polity: Cambridge, UK. Baker S (ed) (2015) Preserving Popular Music Heritage: Do-It-Yourself, Do-ItTogether. Routledge: London.

Beaumont M (2012) New Order Monstrous and Magnificent But Lack Hook's Heft. The Guardian, 12 May p 5.

Berry M and Faulkner D (1998) Bez: Freaky Dancin. Pan: London.

Bickerdike JO (ed) (2016) Joy Devotion: The Importance of Ian Curtis and Fan Culture. Headpress: London.

Black B (2012) Shooters: Guns and Gangs in the Twenty First Century. Milo: Wrea Green, UK.

Blaney C (2014) The Undesireables: The Inside Story of the Inter-City Jibbers. John Blake: London.

Bret D (2004) Morrissey: Scandal and Passion. Robson Books: London.

Brown L (2008) Meetings With Morrissey. Omnibus: London.

Butterworth M (2016) The Blue Monday Diaries: In the Studio with New Order. Plexus: London.

Campbell S and Coulter C (eds) (2010) Why Pamper Complexities? Essays on The Smiths. Manchester University Press: Manchester, UK.

Carman R (2006) Johnny Marr: The Smiths and the Art of Gun-Slinging. IMP: Church Stretton, UK.

Carter H (2005) 'Stacks of Potential'. The Guardian 15 June.

Cawthorne N (2005) The Making of The Stone Roses. Unanimous: London.

Champion S (1990) And God Created Manchester. Wordsmith: Manchester, UK.

Cummins K (2015) New Order. Rizzoli: New York.

Cummins K (2010) Joy Division. Rizzoli: New York.

Cummins K (2009) Manchester: Looking For The Light Through The Pouring Rain. Faber and Faber: London.

Cummins K (2008) Juvenes: The Joy Division Photographs of Kevin Cummins. Fuel: London.

Cummins K (2002) The Smiths and Beyond. Vision On: London.

Curtis I (2014) So This is Permanence. Faber and Faber: London.

Curtis D (1995) Touching From A Distance: Ian Curtis and Joy Division. Faber and Faber: London.

Duffett M (ed) (2014) Popular Music Fandom: Identities, Roles And Practices. Routledge: London.

Edge B (1988) New Order + Joy Division: Pleasures and Wayward Distractions. 2nd edition, Omnibus: London.

Fletcher T (2012) A Light That Never Goes Out: The Enduring Saga of The Smiths. Heinemann: London.

Florida R (2010) The Rise of the Creative Class Revisited. Basic Books: New York.

Florida R (2008) Who's Your City? How The Creative Economy Is Making The Place Where You Live The Most Important Decision of Your Life. Basic Books: New York.

Florida R (2005a) Cities and the Creative Class. Routledge: London.

Florida R (2005b) The Flight of the Creative Class. Harper Collins: New York.

Flowers C (1995) New Order+Joy Division. Omnibus: London.

Gallagher P and Christian T (1996) Brothers: From Childhood to Oasis - The Real Story. Virgin: London.

Gatenby P and Gill C (2011) The Manchester Musical History Tour. Empire: Manchester, UK.

Gatenby P (2007) Panic on the Streets: The Smiths and Morrissey Location Guide. Reynolds and Hearn: Richmond, UK.

Gatenby P (2002) Morrissey's Manchester: The Essential Smiths Tour. Empire: Manchester, UK.

Goddard M and Halligan B (eds) (2010) Mark E. Smith and The Fall: Art, Music and Politics. Ashgate: Aldershot, UK.

Goddard S (2004) The Smiths: Songs That Saved Your Life. Reynolds and Hearn: Richmond, UK.

Green A (2006) The Stone Roses. Continuum: London.

Hall S and Winlow S (2015) Revitalising Criminological Theory: Towards a New Ultra Realism. Routledge: London.

Harrison I (2012) 'Dreams Never End', Mojo no. 219. February.

Haslam D (2015) Life After Dark: A History of British Nightclubs and Music Venues. Simon and Schuster: London.

Haslam D (1999) Manchester, England. Fourth Estate: London.

Hewitt C (2014) Martin Hannett: Pleasures of the Unknown. Ozit Morpheus and Dandelion Records Books: Northwich, UK.

Hewitt P (1997) Getting High: The Adventures of Oasis. Boxtree: London.

Hewitt P (1999) Forever The People: Six Months on the Road With Oasis. Boxtree: London.
Hickey D (2012) From Heaven to Heaven: New Order Live: The Early Years (19811984) at Close Quarters. Hickey: Bedford, UK.

Hook P (2016) Substance: Inside New Order. Simon and Schuster: London.

Hook P (2012) Unknown Pleasures: Inside Joy Division. Simon and Schuster: London.

Hook P (2009) The Hacienda: How Not To Run A Club. Simon and Schuster: London.

Hough I (2007) Perry Boys: The Casual Gangs of Manchester and Salford. Milo: Wrea Green, UK.

Hutton C and Kurt R (1997) Don't look Back In Anger: Growing up with Oasis. Simon and Schuster: London.

Kennedy J (2006) Joy Division and the Making of Unknown Pleasures. Unanimous: London.

Lawson A (1992) It Happened In Manchester: The True Story of Manchester's Music 1958-1965. Multimedia: Manchester, UK.

Leadbeater C (2009) We-Think. Profile.Charles: London.

Leadbeater C (2002) Up The Down Escalator: Why The Global Pessimists Are Wrong. Viking: London.

Leadbeater C (1999) Living On Thin Air: The New Economy. Viking: London.

Leadbeater C (1998) Welcome to the knowledge economy. In: Hargreaves I and Christie I (eds). Tomorrow's Politics: The Third Way and Beyond. Demos: London.

Leadbeater C and Oakley K (2001) Surfing The Long Wave: The Rise Of The Knowledge Entrepreneur. Demos: London.

Leadbeater C and Oakley K (1999) The Independents: Britain's New Cultural Entrepreneurs. Demos: London.

Lee CP (2007) When We Were Thin: Music, Madness and Manchester. Hotun Press: Manchester, UK.

Lee CP (2002) Shake, Rattle and Rain: Popular Music Making in Manchester 19551995. Hardinge Simpole: Ottery St Mary, UK.

Lester P (2010) 'Never Mind the Buzzcocks'. The Guardian 22 January.

Marx K and Engels F (1969) Manifesto of the Communist Party. Progress Publishers: Moscow.

Marr J (2016) Set The Boy Free. Century: London.

McCarroll T (2010) Oasis: The Truth. John Blake: London.

Middles M (2012) Breaking Into Heaven: The Rise and Fall of The Stone Roses. Omnibus: London.

Middles M (2009) Factory: The Story of the Record Label. Virgin: London.

Middles M and Smith ME (2003) The Fall. Omnibus: London.

Middles M (1997) Shaun Ryder: Happy Mondays, Black Grape and Other Traumas. IMP: London.

Middles M (1996) Oasis: Round Their Way. IMP: London.

Middles M (1985) The Smiths. Omnibus: London.

Middles M and Reade L (2006) Torn Apart: The Life of Ian Curtis. Omnibus: London.

Moody P (1996) Oasis: Lost Inside. UFO Music: London.

Morley P (2007) Joy Division: Piece by Piece: Writing About Joy Division 1977-2007. Plexus: London.

Nice J (2010) Shadowplayers: The Rise and Fall of Factory Records. Aurum: London.

Nolan D (2009) You're Entitled To An Opinion: The High Times and Many Lives of Tony Wilson, Factory Records and The Hacienda; John Blake: London.

Nolan D (2007a) I Swear I Was There: The Gig That Changed The World. IMP: 2nd edition, Church Stretton, UK.

Nolan D (2007b) Bernard Sumner - Confusion: Joy Division, Electronic and New Order Versus The World. IMP: Church Stretton, UK.

O'Connell M (2006) Already In Me: With and Without The Roses. Chrome Dreams: New Malden, UK.

O'Neill J (2008) Crime City: Manchester's Victorian Underworld. Milo: Wrea Green, UK.

Reade L (2010) Mr Manchester and the Factory Girl: The Story of Tony and Lindsay Wilson. Plexus: London.

Ranciere J (2009) The Future of the Image. Verso: London.

Redhead S (2011) We Have Never Been Postmodern: Theory at the Speed of Light. Edinburgh University Press: Edinburgh, UK.

Robb J (2009) The North Will Rise Again: Manchester Music City 1976-1996. Aurum: London.

Robertson M (2006) Factory Records: The Complete Graphic Album. Thames and Hudson: London.

Rylatt K and Scott P (2001) CENtral 1179: The Story of Manchester's Twisted Wheel Club. Be Cool: London.

Savage J (ed) (1992) The Hacienda Must be Built. IMP: London.

Sharp C (2007) Who Killed Martin Hannett? Aurum: London.

Simpson D (2008) The Fallen: Searching for the Missing Members of The Fall. Canongate: Edinburgh, UK.

Smith ME (2008) Renegade: The Lives and Tales of Mark E. Smith. Viking: London. Spence S (2014) Happy Mondays - Excess All Areas: A Biography. Aurum: London. Spence S, Donnelly A and Donnelly C (2013) Still Breathing: The True Adventures of the Donnelly Brothers. Black and White Publishing: Edinburgh, UK. 
Spence S (2012) The Stone Roses: War and Peace. Viking: London.

Standing G (2016) The Corruption of Capitalism: Why Rentiers Thrive and Work Does Not Pay. Biteback: London.

Start SB (2016) The Rise, The Fall, The Rise. Faber and Faber: London.

Sumner B (2014) Chapter and Verse: New Order, Joy Division and Me. Bantam: London.

Sykes B (2012) Sit Down, Listen To This: The Story of Roger Eagle. Empire: Manchester, UK.

Thompson D (2005) True Faith: An Armchair Guide To New Order, Joy Division, Electronic, Revenge, Monaco and The Other Two. Helter Skelter: London.

Urry J (2016) What Is The Future?. Polity: Cambridge, UK.

Virilio P and Lotringer S (2008) Pure War. Semiotext(e): Los Angeles, CA.

Verrico L (1998) High Life ' $n$ ' Low Down Dirty: The Thrills and Spills of Shaun Ryder. Ebury Press: London.

Walsh P (2003) Gang War. Milo: Wrea Green, UK.

Warburton J (2000) Hallelujah! The Extraordinary Return of Shaun Ryder and Happy Mondays. Virgin: London.

Wild P (ed) (2007) Perverted By Language: Fiction Inspired by The Fall. Serpent's Tail: London.

Wilson T (2002) Twenty Four Hour Party People: What The Sleeve Notes Never Tell You. Channel 4 Books: London.

Zizek S (2014) Trouble in Paradise: From the End of History to the End of Capitalism. Allen Lane: London.

Zizek S (2013) Demanding The Impossible. Polity: Cambridge, UK.

\section{Data availability}

Data sharing not applicable to this article as no datasets were analysed or generated.

\section{Additional information}

Competing interests: The author declares that there are no competing interests

Reprints and permission information is available at http://www.palgrave-journals.com/ pal/authors/rights_and_permissions.html

How to cite this article: Redhead S (2017) Day in, day out: pop goes the city. Palgrave Communications. 3:17036 doi: 10.1057/palcomms.2017.36.

Publisher's note: Springer Nature remains neutral with regard to jurisdictional claims in published maps and institutional affiliations.

(c) (i) This work is licensed under a Creative Commons Attribution 4.0 International License. The images or other third party material in this article are included in the article's Creative Commons license, unless indicated otherwise in the credit line; if the material is not included under the Creative Commons license, users will need to obtain permission from the license holder to reproduce the material. To view a copy of this license, visit http://creativecommons.org/licenses/by/4.0/

(C) The Author(s) 2017 